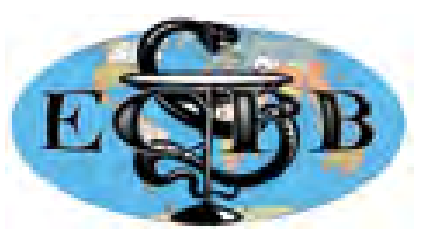

“ЕКСПЕРИМЕНТАЛЬНА ТА КЛІНІЧНА ФІЗІОЛОГІЯ І БІОХІМІЯ” "EXPERIMENTAL AND CLINICAL PHYSIOLOGY AND BIOCHEMISTRY" Науково-практичний журнал/Scientific-practical journal

\title{
The Role of Cholecalciferol in the Reduction of Insulin Resistance and Rehabilitation of Women with Primary Hypothyreosis
}

\author{
O.S. PAYENOK ${ }^{1}$, I.V. PANKIV ${ }^{2}$, A.V. PAYENOK ${ }^{1}$ \\ ${ }^{1}$ Danylo Halytskyi Lviv National Medical University, Lviv, Ukraine \\ ${ }^{2}$ Higher State Educational Establishment of Ukraine "Bukovinian State Medical University", \\ Chernivtsi, Ukraine
}

\section{E-mail: alex.payenok@gmail.com}

Introduction. The insufficiency and deficiency of vitamin D is a global health problem. It is known that vitamin D has some immunomodulatory effects in autoimmune thyroid diseases [1]. Numerous non-skeletal diseases associated with vitamin D deficiency have been reported recently, including hypothyroidism [2]. Some studies have shown that vitamin D may play a glucose tolerance through its effects on insulin secretion and sensitivity [3].

In comparison with a healthy control group, patients with hypothyroidism have a significantly lower circulating concentration of $25(\mathrm{OH}) \mathrm{D}$ [4]. Vitamin D reduces insulin resistance probably through its effect on calcium and phosphorus metabolism and through the regulation of the insulin receptor gene [5].

Considering the discordant results, the direct association between the thyroid autoimmunity and newly identified hypothyroidism in the context of type 2 diabetes mellitus [6], and evidence implying a detrimental role of hypothyroidism in insulin sensitivity [7], it could be stated that the association between insulin resistance and thyroid autoimmunity requires further clarification from both the clinical and research perspectives.

In this study our aim is to evaluate the effects of vitamin D supplementation on insulin resistance in women with primary hypothyroidism.

Materials and Methods. 72 women, aged 31-75 took part in the study during twelve weeks. Cholecalciferol was added to their medication and the data before and after their supplementation were recorded. During the trial women were instructed not to change the dose of levothyroxine. All participants were checked for thyroid stimulating hormone (TSH) and insulin levels. Serum $25(\mathrm{OH}) \mathrm{D}$ was measured by a radioimmunoassay. HOMA-IR (Hemostatic model assessment-Insulin resistance) was calculated. The liver function was assessed by measuring the serum concentration of aspartate aminotransferase and alanine aminotransferase to exclude the liver disease and major non-alcoholic fatty disease of the liver as exclusion criteria that might affect vitamin D metabolism.

The main inclusion criteria were absence of hepatic, renal and bone diseases, malignancy, any history of the use of drugs such as anticonvulsants, calcium, vitamin D.

The written consent was obtained from all participants. After baseline assessment all patients had been taking 21,000 units of cholecalciferol weekly during 12 weeks. During the treatment, all patients were visited and inter- 
viewed about possible side effects, and to determine the degree of compliance. After 12 weeks of treatment, all laboratory tests and clinical evaluations were made again after the initial visit.

The Medical Ethics Committee of Bukovinian State Medical University approved the study protocol which complied with the current version of the Declaration of Helsinki.

The statistical analysis was performed using Statistics Package «Statistica 10» (StatSoft Inc., USA). The data were analyzed by descriptive tests such as mean, SD (standard deviation), SE (Standard Error) and K-S (Kolmogorov-Smirnov) tests which were performed to assess the normality of the variables before the further statistical analysis. All data in this study are presented as mean \pm SD. The effects of Vitamin D supplementation on the variables were analyzed by a paired t-test (for normally distributed) or the Wilcoxon test (for non-normally distributed).

Results and discussion. The average age of the participants was $44.8 \pm 10.1$ years old. The average weight of the patients at the beginning was $71 \pm 11$ and at the end was $70 \pm 9 \mathrm{~kg}$ that doesn't have a meaningful difference. All women were controlled with levothyroxine as monotheraphy. Mean 25(OH)D concentration was $21.94 \pm 6.31 \mathrm{ng} / \mathrm{ml}$ at the beginning and all patients had vitamin D deficiency based on $25(\mathrm{OH}) \mathrm{D}<30 \mathrm{ng} / \mathrm{ml}$. TSH before and after treatment was normally distributed, so it was analyzed by a paired t-test. But HOMA-IR and insulin before and after treatment were non-normally distributed, so they were analyzed by the Wilcoxon test.

The insulin concentration has decreased significantly after the treatment with cholecalciferol $(p=0.034)$. The comparison of mean for HOMA-IR before and after treatment with vitamin $\mathrm{D}$ has shown a meaningful reduction after the supplementation (Table 1).

Table 1

Comparison of biochemical characteristics (mean \pm SD) in women with primary hypothyroidism before and after treatment with cholecalciferol during 12 weeks

\begin{tabular}{|c|c|c|c|}
\hline Variable & before treatment & after treatment & P-value \\
\hline TSH, mIU/L & 7.6 & 7.1 & 0.15 \\
\hline Insulin, mIU/L & $18.37 \pm 2.48$ & $10.19 \pm 2.13$ & 0.041 \\
\hline HOMA-IR & $3.97 \pm 0.36$ & $2.32 \pm 0.18$ & 0.039 \\
\hline $25(\mathrm{OH}) \mathrm{D}, \mathrm{ng} / \mathrm{ml}$ & $21.94 \pm 6.31$ & $37.28 \pm 6.82$ & 0.036 \\
\hline
\end{tabular}

Twelve weeks of cholecalciferol supplementation has not changed the lipid profile in patients with hypothyroidism.

The aim of this study was to investigate the effects of vitamin D supplementation on serum insulin and HOMA-IR in women with primary hypothyroisdism. There has been an inverse relation between final TSH and basal $25(\mathrm{OH}) \mathrm{D}$ concentration. Higher serum basal $25(\mathrm{OH}) \mathrm{D}$ has led to the lower final TSH. This may be because of non-skeletal effects of vitamin D which appears in higher vitamin D concentration and the effects of lower vitamin D concentration are limited to the bone and muscle.

Effects of vitamin D supplementation on insulin resistance have been shown in numerous studies. Our findings are consistent with the results of many other published studies in which the insulin resistance appeared to decrease in patients with hypothyroidism who had received vitamin D. Von Hurst showed that vitamin D supplementation improved the insulin sensitivity and insulin resistance significantly [8].

The monthly supplementation of 120,000 units of vitamin D has also improved insulin sensitivity [9]. Although in contrast to some studies, Witham M.D. et al. found out that vitamin D intake (in different dosage form) had no effects on insulin resistance [10]. Nagpal J. et al. reported that vitamin D 
supplementation had no effect on mean of insulin sensitivity but two years treatment with vitamin D did improve HOMA-IR [11].

There are some mechanisms of the effects of vitamin $\mathrm{D}$ : the presence of vitamin $\mathrm{D}$ receptors on pancreatic B-cells. Vitamin D activating $1 \alpha$-hydroxylase is expressed in pancreatic B-cells, the presence of vitamin D response element in the insulin gene, the presence of vitamin $\mathrm{D}$ receptor in skeletal muscle and the fact that $1,25(\mathrm{OH}) \mathrm{D}$ increases the transcription of insulin receptor genes [12].

The limitation of our study is that we have not evaluated the effects of placebo on insulin or HOMA-IR.

Conclusion. Vitamin D deficiency is common in women with primary hypothyroidism. Our data have shown some significant improvement in serum insulin and in HOMA-IR after treatment with cholecalciferol.

The author declares no conflict of interests.

\title{
REFERENCES (ПОСИЛАННЯ)
}

1. Wang $J$, Lv S, Chen $G$, Gao $C$, He J, Zhong $H$ et al. Meta-analysis of the association between vitamin $\mathrm{D}$ and autoimmune thyroid disease. Nutrients. 2015;7:2485-98.

2. Mackawy AMH, Al-ayed BM, Al-rashidi BM. Vitamin D deficiency and its association with thyroid disease. International Journal of Health Sciences. (Qassim). 2013;7(3):267-275. PMCIS:PMC3921055

3. As Al-Shoumer K, Al-Essa TM. Is there a relationship between vitamin D with insulin resistance and diabetes mellitus. World Journal Diabetes. 2015;6(8) :1057-64 doi: 10.4239/wjd. v6.i8.1057

4. Toulis K, Tsekmekidou X, Potolidis E, Didangelos T, Gotzamani-Psarrakou A, Zebekakis P. et al. Thyroid autoimmunity in the context of type 2 diabetes mellitus: implications for vitamin D. International Journal Endocrinoly. 2015;710363. doi: 10.1155/2015/710363.

5. Palomer X, Gonzalez-Clemente JM, Blanco-Vaca F, Mauricio D. Role of vitamin D in the pathogenesis of type 2 diabetes mellitus. Diabetes, Obesity and Metabolism. 2008;10:185-197. doi: $10.1111 / \mathrm{j} .1463-1326.2007 .00710 . x$.

6. Díez JJ, Iglesias $P$. An analysis of the relative risk for hypothyroidism in patients with Type2 diabetes. Diabetic Medicine. 2012;29(12):1510-14. doi: 10.1111/j.1464-5491.2012.03687.x.

7. Duntas LH, Orgiazzi J, Brabant G. The interface between thyroid and diabetes mellitus. Clinical Endocrinology. 2011;75(1):1-9. doi: 10.1111/j.1365-2265.2011.04029.x.

8. Von Hurst PR, Stonehouse W, Coad J. Vitamin D supplementation reduces insulin resistance in south Asian Women living in New Zealand. Br J Nutr. 2009;28:1-7.

9. Pittas AG, Harris SS, Stark PC, Dawson-Hughes B. The effects of calcium and vitamin D supplementation on blood glucose and markers of inflammation in non-diabetic adults. Diabetes Care. 2007;30(4):980-86. doi: 10.2337/dc06-1994.

10. Witham MD, Dore FJ, Druburgh M, Sugden JA, Morris AD, Struthers AD. The effect of different doses of vitamin D3 on markers of vascular health. Diabetologia. 2010;53(10):2112-19. doi: $10.1007 / \mathrm{s} 00125-010-1838-1$.

11. Nagpal J, Pande JN, Bhartia A. A double-blind, randomized, placebo-controlled trial of the short-term effect of vitamin D3 supplementation on insulin sensitivity in apparently healthy, middle-aged, centrally obese men. Diabetic Medicine. 2009;26(1):19-27. doi: 10.1111/j.14645491.2008.02636.x.

12. Bland R, Markovic D, Hills CE, Hughes SV, Chan SL, Squires PE. Expression of 25-hydroxyvitamin D3-1alpha-hydroxylase in pancreatic islets. Journal of Steroid Biochemistry and Molecular Biology. 2004;89-90(1-5):121-5.

Стаття надійшла до редколегії 30.11.2018

\section{RESEARCH ARTICLE}

\section{The Role of Cholecalciferol in the Reduction of Insulin Resistance and Rehabilitation of Women with Primary Hypothyreosis}

\author{
O.S. PAYENOK ${ }^{1}$, I.V. PANKIV ${ }^{2}$, A.V. PAYENOK ${ }^{1}$ \\ ${ }^{1}$ Danylo Halytskyi Lviv National Medical University, Lviv, Ukraine \\ ${ }^{2}$ Higher State Educational Establishment of Ukraine "Bukovinian State Medical University", \\ Chernivtsi, Ukraine \\ E-mail: alex.payenok@gmail.com
}

Background. Vitamin D deficiency is one of the risk factors for insulin resistance and there is a relationship between hypovitaminosis of vitamin $\mathrm{D}$ with the prevalence of primary hypo- 
thyroidism. The effect of cholecalciferol supplementation on insulin resistance in women with primary hypothyroidism has not been investigated before. The aim of the study is to evaluate the role of cholecalciferol supplementation on insulin resistance in primary hypothyroidism.

Materials and methods. 72 women, aged 31-75 took part in the study. Serum thyroid stimulating hormone (TSH), insulin and 25(OH)D concentration were measured and HOMA-IR was calculated. All measurements were performed at the beginning and the end of the study. Women with hypothyroidism had been receiving 21.000 unit of cholecalciferol orally per week during twelve weeks. The results were analyzed by descriptive tests and the comparison between variables was made by using paired T-tests.

Results. All participants had vitamin D deficiency. Mean serum 25(OH)D concentration was $21.94 \pm 6.31 \mathrm{ng} / \mathrm{ml}$. The results at the beginning and at the end were for insulin $18.37 \pm 2.48$ and $10.19 \pm 2.13 \mathrm{mIU} / \mathrm{L}(\mathrm{p}=0.041)$ and for HOMA-IR, $3.97 \pm 0.36$ and $2.32 \pm 0.18(\mathrm{p}=0.039)$, respectively.

Conclusion. Vitamin D deficiency is common in women with primary hypothyroidism. Our data have shown some significant improvement in serum insulin and in HOMA-IR after treatment with cholecalciferol.

Key words: hypothyroidism, women, insulin resistance, cholecalciferol, rehabilitation. 